\title{
NUTRITIONAL CONTENT AND A PHASE - I SAFETY CLINICAL TRIAL OF A HERBAL-NUTRITIONAL SUPPLEMENT (IMUNITI) WITH PUTATIVE IMMUNE-MODULATING PROPERTIES
}

\author{
M.G. Matsabisa ${ }^{1 *}$, M.P. Sekhoacha' ${ }^{1}$, O. Ibrahim², P. Moodley³, M. Faber ${ }^{4}$
}

Email: Motlalepula.matsabisa@mrc.ac.za

1 IKS Lead Programme, South African Medical Research Council, Francie van Zyl Drive Parow valley, Cape Town, ${ }^{2}$ Brenthurst Clinic Parktown Johannesburg, ${ }^{3}$ Private GP, Durban South Africa, ${ }^{4}$ Nutrition intervention group, South African Medical Research Council Francie van Zijl Drive Parow valley Cape Town

Abstract

The relationship between HIV and AIDS and poor nutrition has been well established. Poor nutrition hastens the progression of HIV infection to AIDS. The rising pandemic of HIV and AIDS and high toxicity associated with anti-retroviral use are major factors that have compelled research to explore traditional herbal medicines as potential alternatives or supplements to anti-retroviral agents. A Phase I clinical trial was conducted on IMUNITI Wellness Pack, a herbal product with putative immune-modulating properties. The product is a combination of 7 herbal preparations, minerals, vitamins, and a specially formulated soya-maize meal porridge and a bottle of water purifier. The aim was to evaluate the safety and tolerability of IMUNITI, with a purpose of developing it for use in HIV-infected patients. The phase I study was conducted at the MRC clinic in Botha's hill and the study lasted 5 weeks from date of participant dosing. The study was a randomised blinded placebocontrolled phase I clinical trial conducted on 48 healthy males. The participants were randomly divided into 4 groups of 12 . The 3 groups received different escalating doses of IMUNITI while the forth group received placebo tablets. Participants consumed IMUNITI daily for a period of 5 weeks. Assessments were done at baseline, week 1 and week 5 to determine the safety parameters in all participants. In this study, IMUNITI did not show any safety concerns. In all study participants, there were no significant changes above the upper limit of the reference ranges of the laboratory tests for full blood count, INR, renal and biochemical safety parameters. IMUNITI was well tolerated. Furthermore, the nutritional content analysis of IMUNITI showed that it is a high kilojoule, high protein content product which contains a mixture of sugars, vitamins, traces of calcium, phosphorus and minerals.

Key words: HIV and AIDS, Immune booster, herbal product, traditional medicines

Introduction

An estimated 5.6 million people were living with HIV and AIDS in South Africa in 2009, more than in any other country (UNAIDS 2010). HIV and AIDS accounted for 310,000 deaths in South Africa, resulting in 1.9 million AIDS orphans, of which 330,000 were living with HIV. Prevalence is high among those aged 15-49; almost one-in-three women aged 25-29, and over a quarter of men aged 30-34 are living with HIV (HRSC 2009; Statistics South Africa 2008, 2010).

South Africa has the largest antiretroviral therapy programme in the world, but given the magnitude of the epidemic, access to treatment is low (Meyer-Rath, G et al., 2010). Only about 37\% of infected people were receiving treatment for HIV. Meanwhile at least 30 people were dying daily due to their inability to access ARVs (Cornell, 2010; Mail and Guardian 2009). Also, starting treatment at a CD4 count of $<350$ cells $/ \mathrm{mm}^{3}$ according to the WHO guidelines led to increased demand for ARVs (WHO/UNAIDS/UNICEF 2010). The increased deployment of ARVs and an influx of new patients put a strain on the administrative capacity of health authorities, which lead to poor service delivery (Peris, 2010; Health-e 2010). This inadequate supply of ARVs lead to interrupted treatment, which together with the non-adherence to the life-time long therapy, promote risk for drug resistance (Krakovska et al., 2007; Harrison, 2009., DoH 2010). These challenges emphasise the need for more affordable, easily accessible short term treatment for HIV and AIDS. One unexplored avenue is traditional medicines and development of medicinal herbal products that have antiviral and immune boosting properties. Strengthening the use of scientifically validated traditional medicines in a comprehensive scientific and clinical-based approach, and provision of good nutrition to HIV and AIDS patients could result in drastic reduction of the burden of HIV and AIDS.

The aim of the study presented here was to evaluate the safety and tolerability of IMUNITI Wellness Pack, with the aim of further developing it for use in HIV-infected patients. IMUNITI Wellness Pack is a nutritional herbal product with putative immune-modulating properties. It is a combination of 7 nutritional and herbal medicinal plants, namely, Sutherlandia, African Potato, Chinese Green Tea, Spirulina, Rooibos supplemented with selenium and Zinc, and with the Aloe vera juice which is supplemented with Vitamin C. In addition to these components, the pack contains a specially formulated soya-maize meal porridge and a bottle of water purifier. There are some various anecdotal evidences of the health benefits of IMUNITI Wellness Pack on HIV infected individuals. This evidence can, however, not be used as a basis for the supply of IMUNITI to the larger public. Credible scientific evidence supporting these anecdotes and the safety of the product under controlled conditions need to be provided if the product is to be made available to the public (De Smet, 1995).

\section{Materials and Methods}

Study Participants

The study was conducted at the MRC clinical trial site in Valley of Thousand Hills, Botha's Hill in KwaZulu Natal. Forty eight (48) 
healthy male volunteers between the ages of 18 to 45 were recruited for the study. Participants were recruited from neighbouring villages in Bothas Hill, Kwa-Zulu Natal, South Africa. All subjects were in good health as determined by medical history, physical examination, vital signs, and clinical laboratory measurements. To be included in the study, the participants had to be able to give informed consent, test sero negative for HIV and be between $\geq 18$ and $\leq 45 y$ ears of age. The exclusion criteria are summarized as follows: 1) History suggestive of tuberculosis (TB), and Diabetes mellitus. 2) On treatment for chronic illness e.g. diabetes, arthritis, TB etc. 3) On medication for immune modulation, herbal medicines, traditional medicines or multivitamins. 4) Excessive Smoking (nicotine dependence). 5) Excessive alcohol dependence. 6) Sero-positive for HIV. The study was approved by the South African Medical Research Council Ethics Committee. All participants included in the trial gave written prior informed consent to participate. Participants had the right to withdraw at any moment by immediately contacting the investigators to inform them, without obligation to provide reasons.

\section{Study design}

This study employed a double-blind placebo-controlled design. The product was tested at three different doses. Participants were randomly assigned to one of four treatment groups of 12 ( Table 2).. The first group received a standard recommended daily dose of the supplements (Table 1). The second group and third group each received twice and thrice the recommended daily dose, respectively. The fourth group received the standard IMUNITI Wellness Pack but with placebo tablets containing insipient only. Groups $1-3$ received $150 \mathrm{ml}$ Aloe Vera juice, but diluted for Groups $1 \& 2$ (Group 1; $50 \mathrm{ml}$ juice $+100 \mathrm{ml}$ Aloe Vera flavoured water and Group 2; $100 \mathrm{ml}$ juice $+50 \mathrm{ml}$ Aloe Vera flavoured water). Group 4 received $150 \mathrm{ml}$ Aloe Vera flavoured water to blind the treatment. Aloe Vera juice was diluted at the manufacturing stage at Impilo drugs, Kwa-Zulu Natal.

Participants met daily at pre-determined venues to take the study medication under the supervision of the field monitor.The study medication was administered between 7:00 and 10:00 hrs daily for 5 weeks. The porridge included in the IMUNITI Wellness Pack was standard for all four groups. The study blinding was maintained by making the placebo tablets similar in appearance to the active study medication and by using Aloe Vera flavoured water.

Table 1. Recommended daily does of IMUNITI Wellness Pack

\begin{tabular}{|c|c|c|c|}
\hline Constituent & Strength & Recommended daily & Total Daily intake \\
\hline Sutherlandia & $300 \mathrm{mg}$ & 2 tablets & $600 \mathrm{mg}$ \\
\hline African potato & $300 \mathrm{mg}$ & 1 tablet & $300 \mathrm{mg}$ \\
\hline $\begin{array}{l}\text { Rooibos incl. } \\
\text { Selenium } \\
\text { Zinc }\end{array}$ & $\begin{array}{l}175 \mathrm{mg} \\
0.2 \mathrm{mg} \\
50 \mathrm{mg}\end{array}$ & 1 tablet with food & $\begin{array}{l}175 \mathrm{mg} \\
0.2 \mathrm{mg} \\
50 \mathrm{mg}\end{array}$ \\
\hline Pure Spirulina & $500 \mathrm{mg}$ & 1 tablet & $500 \mathrm{mg}$ \\
\hline Chinese Green Tea & $150 \mathrm{mg}$ & 1 tablet & $150 \mathrm{mg}$ \\
\hline $\begin{array}{l}\text { Aloe vera } \\
+ \text { Vit C }\end{array}$ & $\begin{array}{l}\text { 400mg per } 50 \mathrm{ml} \\
60 \mathrm{mg} \text { per } 50 \mathrm{ml}\end{array}$ & Take 50ml daily & $60 \mathrm{mg}$ \\
\hline Porridge (Soya + Maize) or & $\begin{array}{c}50 \mathrm{~g} \\
100 \mathrm{~g}\end{array}$ & $\begin{array}{c}2 \text { heaped tablespoons with water or milk twice daily } \\
4 \text { heaped tablespoons with water or milk }\end{array}$ & \\
\hline Blue Gold natural water purifier & Drops & & \\
\hline Tap or bottled water & & 1 drop per 1 litre and left for 1 minute & \\
\hline \multicolumn{3}{|c|}{ Total daily consumption } & $1835.2 \mathrm{mg}$ \\
\hline
\end{tabular}

Table 2. Study design and dosage; three study groups received Wellness Pack daily at three different doses while the fourth group received placebo tablets. Porridge was standard for all groups.

\begin{tabular}{|c|c|c|c|c|c|}
\hline \multirow[t]{2}{*}{ Group } & \multirow{2}{*}{$\begin{array}{l}\text { Participants } \\
(n=48)\end{array}$} & \multicolumn{4}{|c|}{ Dose/day } \\
\hline & & \# Wellness Pack/ day (Active) & $\begin{array}{l}\text { Placebo } \\
\text { Tablets }\end{array}$ & Aloe Vera (mL) & Porridge (g) \\
\hline 1 & 12 & $\begin{array}{l}\text { commended (Recommended as in pack }+12 \text { place } \\
\text { tablets }\end{array}$ & 12 & $\begin{array}{l}50 \text { mL juice + } \\
100 \text { mL water* }\end{array}$ & 100 \\
\hline 2 & 12 & $\begin{array}{c}\text { x (Recommended Wellness Pack but twice number } \\
\text { tablets }+6 \text { placebo tablets) }\end{array}$ & 6 & $\begin{array}{l}100 \mathrm{~mL} \text { juice + } \\
50 \mathrm{~mL} \text { water }\end{array}$ & 100 \\
\hline 3 & 12 & $\begin{array}{c}\text { (Recommended Wellness Pack but with three tim } \\
\text { the number of tablets) }\end{array}$ & 0 & $150 \mathrm{~mL}$ juice & 100 \\
\hline 4 & 12 & $\begin{array}{c}\text { acebo (Recommended Wellness Pack with } 18 \text { place } \\
\text { tablets }\end{array}$ & 18 & $150 \mathrm{~mL}$ water & 100 \\
\hline
\end{tabular}

\section{Safety Assessments}

Assessment of product safety included clinical observation and monitoring of haematological and biochemical parameters; liver function tests as measured by ALT, AST, GGT and LDH, and renal function tests as measured by Urea, Creatinine and electrolytes clearance. Physical examinations, anthropometry, vital sign measurements and blood sampling for clinical laboratory testing were performed at a screening assessment, which occurred within 28 days prior to baseline assessments and administration of the first dose of study medication. Similar followup assessments were done at week 1 and week 5 . All observed and volunteered adverse events (AEs) were recorded daily by field monitors using health assessment questionnaires and by a clinician on standardized case report forms. An independent monitoring safety committee - 
Data and Safety Monitoring Board (DSMB) - was created to evaluate the safety of the product by reviewing AEs encountered. The Division of AIDS Table for grading the severity of Adult Adverse Events (DAIDS grading table) wherein a grading severity scale is provided for each possible laboratory test was utilized for AE reporting in this study. Arrangements were made with hospital management at Grey's Hospital, Pietermaritzburg, for participants needing emergency treatment or hospitalisation.

\section{Data analysis}

The effect of each dose at different visits on the clinical, haematology and biochemical variables, were assessed by an Analysis of Variance (ANOVA). Individual comparisons between groups were made using Scheffe's acceptance test for post hoc comparisons. A p-value < 0.05 was indicative of statistical significance. SAS version 9.2 was used for all analysis, including the basic descriptive statistics.

\section{Nutritional content of the IMUNITI Wellness Pack}

The nutritional content of IMUNIT wellness pack was evaluated without the porridge. The evaluation was outsourced to the Agricultural Research Council (ARC) analysing laboratory, which holds SANAS accreditation for analyses and an ASM number. The samples received were thoroughly mixed before analysis as per manufacturer's instruction of reconstituting the IMUNITI Pack.

\section{Results}

Participants

A total of 90 male participants were available for screening for the study. Participants that tested positive for HIV, had grade 3 laboratory abnormalities or tested positive for hepatitis B were excluded. A total of 48 participants were successfully recruited and only 46 completed the study. Two participants dropped out of the study due to reasons not related to the study drug. There was $95.8 \%$ adherence to the study.

\section{Results of laboratory tests}

The DAIDS grading table was used as criteria for AE reporting. In general, the volunteers showed values within the limits of normality in the results of the clinical tests in the all visits throughout the study. There were no significant changes in all study participants across all dosage groups in the haemoglobin concentration, the MCV values, iron and ferritin levels. IMUNITI had no effect on the metabolism B12, folate and the absorption of iron from the gastrointestinal tract. INR values were within limits showing that IMUNITI did not inhibit vitamin $\mathrm{K}$ absorption in the gastrointestinal tract. None of the biochemical safety parameters were above a grade 2 according to the DAIDS table. Random glucose levels were within normal ranges.

\section{Adverse events}

No deaths or serious AEs occurred. No AEs were reported by the field monitors. No study participants reported any significant side-effects such as headaches, nausea, vomiting, diarrhoea, rash, fatigue and sleep disturbances. No AEs or significant changes in physical examination were reported in the Case Report Forms. The overall abnormalities in the biochemical and haematological values using the DAIDS table were considered moderate by study Principle Investigator. There we were no defaulters or discontinuations reported. There was $100 \%$ compliance to the study medication and $95.8 \%$ adherence to the study.

\section{Nutritional content of the IMUNITI pack}

The nutritional content of the IMUNITI Wellness Pack without the porridge is shown in Table 3

Table 3. The nutritional content of IMUNITI. The results relate to RDA of adults above the age of 12. and show the recommended daily dose of the IMUNITI Wellness Pack. Where applicable RDA figures are included for comparison only.

\begin{tabular}{|c|c|c|c|c|}
\hline Analysis & Unit & Sample IMUNITI & RDA & \\
\hline & & & hale Adults (4 Yrs and olde & $\begin{array}{c}\text { aximum Daily consumption of IMUN } \\
(\mathbf{1 8 3 5 . 2 m g})\end{array}$ \\
\hline Calcium & & 0.22 & $800-1300 \mathrm{mg}$ & \\
\hline Phosphorous & & 0.29 & & \\
\hline Dry matter & 94.14 & & \\
\hline Moisture & & 5.86 & & \\
\hline Fat (ether extraction) & & 7.39 & & \\
\hline NDFIN & & 0.045 & & \\
\hline Organic matter (Calculated) & & 89.72 & & \\
\hline Starch & & 35.40 & & \\
\hline Water Soluble Carbohydrates & & 26.54 & & \\
\hline Total non- structural carbohydrates & & 60.40 & & $13 \mathrm{~g} / 100 \mathrm{~g}$ \\
\hline Carbohydrates (calculated) & & 64.20 & & \\
\hline Sugars & & & & \\
\hline
\end{tabular}




\begin{tabular}{|c|c|c|c|c|}
\hline Glucose & $\mathrm{g} / 100 \mathrm{~g}$ & Not detected & & \\
\hline Fructose & $\mathrm{g} / 100 \mathrm{~g}$ & 0.23 & & 0.0042 \\
\hline Sucrose & $g / 100 \mathrm{~g}$ & 19.28 & & 0.3540 \\
\hline Maltose & $g / 100 \mathrm{~g}$ & 1.11 & & 0.0204 \\
\hline Lactose & $\mathrm{g} / 100 \mathrm{~g}$ & Not detected & & \\
\hline Rafinose & $\mathrm{g} / 100 \mathrm{~g}$ & 1.24 & & 0.0228 \\
\hline Stachiose & $\%$ & 1.51 & & \\
\hline \multicolumn{5}{|l|}{ Vitamins } \\
\hline Vit A & $\mathrm{mg} / 100 \mathrm{~g}$ & 0.27 & $400-700 \mathrm{mg}$ & 0.0037 \\
\hline Vit B1 & $\mathrm{mg} / 100 \mathrm{~g}$ & 0.07 & $0.6-1.2 \mathrm{mg}$ & 0.0013 \\
\hline Vit B2 & $\mathrm{mg} / 100 \mathrm{~g}$ & 1.20 & $0.6-1.1 \mathrm{mg}$ & 0.0022 \\
\hline Vit C & $\mathrm{mg} / 100 \mathrm{~g}$ & 22.25 & $25-100 \mathrm{mg}$ & 0.0408 \\
\hline Vit E & $\mathrm{mg} / 100 \mathrm{~g}$ & 5.60 & $7-15 \mathrm{mg} \mathrm{te}$ & 0.1028 \\
\hline \multicolumn{5}{|l|}{ Amino acids } \\
\hline Arginine & $g / 100 g$ & 1.18 & & 0.0217 \\
\hline Serine & $\mathrm{g} / 100 \mathrm{~g}$ & 0.67 & & 0.0123 \\
\hline Aspartic Acid & $\mathrm{g} / 100 \mathrm{~g}$ & 1.18 & & 0.0217 \\
\hline Glutamic Acid & $\mathrm{g} / 100 \mathrm{~g}$ & 2.74 & & 0.0503 \\
\hline Glycine & $\mathrm{g} / 100 \mathrm{~g}$ & 0.69 & & 0.0127 \\
\hline Threonine & $g / 100 g$ & 0.76 & & 0.0140 \\
\hline Alanine & $g / 100 g$ & 0.62 & & 0.0118 \\
\hline Tyrosine & $g / 100 g$ & 0.72 & $14-24 \mathrm{mg} / \mathrm{kg}$ & 0.0132 \\
\hline Proline & $\mathrm{g} / 100 \mathrm{~g}$ & 1.04 & & 0.0191 \\
\hline HO-Proline & $\mathrm{g} / 100 \mathrm{~g}$ & 0.01 & & 0.0002 \\
\hline Metheonine & $g / 100 g$ & 0.15 & $13-24 \mathrm{mg} / \mathrm{kg}$ & 0.0028 \\
\hline Valine & $\mathrm{g} / 100 \mathrm{~g}$ & 0.85 & $13-28 \mathrm{mg} / \mathrm{kg}$ & 0.0156 \\
\hline Phenylalanine & $g / 100 g$ & 0.82 & $14-28 \mathrm{mg} / \mathrm{kg}$ & 0.0151 \\
\hline Isoleucine & $g / 100 g$ & 0.72 & $10-28 \mathrm{mg} / \mathrm{kg}$ & 0.0132 \\
\hline Leucine & $\mathrm{g} / 100 \mathrm{~g}$ & 1.30 & $14-44 \mathrm{mg} / \mathrm{kg}$ & 0.0239 \\
\hline Histidine & $\mathrm{g} / 100 \mathrm{~g}$ & 1.39 & $29 \mathrm{mg} / \mathrm{kg}$ (infants only) & 0.2551 \\
\hline Lysine & $\mathrm{g} / 100 \mathrm{~g}$ & 0.97 & $12-49 \mathrm{mg} / \mathrm{kg}$ & 0.0178 \\
\hline Cysteine & $g / 100 g$ & 0.12 & $13-24 \mathrm{mg} / \mathrm{kg}$ & 0.0022 \\
\hline Tryptophan & $g / 100 g$ & 0.19 & $3-4 \mathrm{mg} / \mathrm{kg}$ & 0.0035 \\
\hline Protein & $\%$ & 18.13 & $56 \mathrm{~g}^{*}$ & \\
\hline \multicolumn{5}{|l|}{ Micro elements } \\
\hline Aluminium & $\mathrm{Mg} / 100 \mathrm{~g}$ & 1.90 & & 0.0349 \\
\hline Boron & $\mathrm{Mg} / \mathrm{kg}$ & 11.50 & $\mathrm{UL}=20 \mathrm{mg}$ & 0.0211 \\
\hline Calcium & $\mathrm{Mg} / 100$ & 159 & $800-1300 \mathrm{mg}$ & 2.918 \\
\hline Chloride & $\mathrm{Mg} / 100 \mathrm{~g}$ & 878 & $1 . .9-3.6 \mathrm{~g}$ & 16.11 \\
\hline Chromium & $\mathrm{Mg} / \mathrm{kg}$ & 1.03 & $15-35 \mu \mathrm{g} / 100 \mathrm{~g}$ & 0.0019 \\
\hline Cobalt & $\mathrm{Mg} / \mathrm{kg}$ & 0.11 & & 0.0002 \\
\hline Flouride & $\mathrm{Mg} / 100 \mathrm{~g}$ & $<15.0$ & $1-4 m g$ & $<0.2753$ \\
\hline Magnesium & $\mathrm{Mg} / 100 \mathrm{~g}$ & 118 & $130-420 \mathrm{mg}$ & 2.1655 \\
\hline Nitrate & $\mathrm{Mg} / 100 \mathrm{~g}$ & 20.80 & & 3.8172 \\
\hline Nitrite & $\mathrm{Mg} / 100 \mathrm{~g}$ & $<20$ & & $<0.3670$ \\
\hline Phosphorus & $\mathrm{Mg} / 100 \mathrm{~g}$ & 367 & $3.8-4.7 g$ & 6.7352 \\
\hline Potassium & $\mathrm{Mg} / 100 \mathrm{~g}$ & 574 & $1,2-1.5 g$ & 10.5340 \\
\hline Sodium & $\mathrm{Mg} / 100 \mathrm{~g}$ & 813 & Low $120 \mathrm{mg} / 100 \mathrm{~g}$ & 14.920 \\
\hline Sulphur & $\mathrm{Mg} / 100 \mathrm{~g}$ & 29.70 & & 0.5451 \\
\hline Sulphate & $\mathrm{Mg} / 100 \mathrm{~g}$ & 89 & & 1.633 \\
\hline Antimony & $\mathrm{Mg} / \mathrm{kg}$ & $<0.1$ & & $<0.0002$ \\
\hline Arsenic & $\mathrm{Mg} / \mathrm{kg}$ & $<0.1$ & & $<0.0002$ \\
\hline Barium & $\mathrm{Mg} / \mathrm{kg}$ & 144 & & 0.264 \\
\hline Cadmium & $\mathrm{Mg} / \mathrm{kg}$ & $<0.1$ & & $<0.0002$ \\
\hline Copper & $\mathrm{Mg} / \mathrm{kg}$ & 7.90 & $440-900 \mu g$ & 0.0145 \\
\hline Iron & $\mathrm{Mg} / \mathrm{kg}$ & 171 & $8-18 \mathrm{mg}$ & 0.3138 \\
\hline Lead & $\mathrm{Mg} / \mathrm{kg}$ & 11.72 & & 0.0022 \\
\hline Manganese & $\mathrm{Mg} / \mathrm{kg}$ & 14.50 & $2.3 \mathrm{mg}$ & 0.0266 \\
\hline Mercury & $\mathrm{Mg} / \mathrm{kg}$ & 0.10 & & 0.0002 \\
\hline Molybdenum & $\mathrm{Mg} / \mathrm{kg}$ & 0.93 & $45 \mu \mathrm{g}$ & 0.0017 \\
\hline Nickel & $\mathrm{Mg} / \mathrm{kg}$ & 6.50 & $\mathrm{UL}=1.0 \mathrm{mg}$ & 0.0119 \\
\hline Nitrogen & $\mathrm{Mg} / 100 \mathrm{~g}$ & 3.24 & & 0.0597 \\
\hline Selenium & $\mathrm{Mg} / \mathrm{kg}$ & $<0.1$ & $30-55 \mu \mathrm{g}$ & $<0.0002$ \\
\hline
\end{tabular}




\begin{tabular}{|c|c|c|c|c|}
\hline Strontium & $\mathrm{Mg} / \mathrm{kg}$ & 3 & & 0.0055 \\
\hline Tin & $\mathrm{Mg} / \mathrm{kg}$ & 0.59 & & 0.0011 \\
\hline Titanium & $\mathrm{Mg} / \mathrm{kg}$ & 5.58 & & 0.0102 \\
\hline Vanadium & $\mathrm{Mg} / \mathrm{kg}$ & $<0.3$ & $\mathrm{UL}=1.8 \mathrm{mg}$ & 0.0006 \\
\hline Zinc & $\mathrm{Mg} / \mathrm{kg}$ & 170 & $5-12 \mathrm{mg}$ & \\
\hline Fibre and Energy & & & & \\
\hline Fibre (crude) & $\%$ & 1.55 & $3 \mathrm{~g} / 100 \mathrm{~g}$ & \\
\hline Neutral detergent fibre & $\%$ & 4.20 & & \\
\hline Dietary fibre (total) & $\%$ & 5.78 & $25-38 \mathrm{~g}$ & \\
\hline Insoluble dietary fibre & $\%$ & 8.31 & & \\
\hline Soluble dietary fibre & $\%$ & Not detected & & \\
\hline In vitro digestibility & $\%$ & 87.73 & & 0.0235 \\
\hline ME calculation & $\mathrm{MJ} / \mathrm{Kg}$ & 12.79 & & 0.0326 \\
\hline Energy & $\mathrm{MJ} / \mathrm{kg}$ & $\mathrm{ASM} 053$ & $170 \mathrm{~kJ} / 100 \mathrm{~g}$ & \\
\hline
\end{tabular}

The Wellness Pack has a high protein content (18\%) with a composition of 10 essential amino acids and 9 non-essential amino acids. The product has a low fat content of only $7.4 \%$ but a high content of starch (35.40\%) and a mixture short chain sugars which contribute to its high kilojoule base $(170 \mathrm{~kJ} / 100 \mathrm{~g})$. Vitamins $\mathrm{A}, \mathrm{B}, \mathrm{C}$ and $\mathrm{E}$, and presence of many micro elements, calcium and phosphorus add to the multi-nutritional value of IMUNITI.

\section{Conclusion}

In this study, IMUNITI did not show any safety concerns. There were no clinically significant consistent changes in laboratory parameters in the groups receiving IMUNITI compared to the Placebo group, over the 5 week study period. IMUNITI was well tolerated by all 3 groups. IMUNITI is a high energy and high protein content product with a mixture of essential amino acids, useful Vitamins and minerals which may boost the immune system, and can therefore contribute to the recovery process in AIDS patients. Since the progression of HIV to AIDS especially in developing countries is exacerbated by poor nutrition and unhygienic environment, the product could be recommended as a basis for a sustainable nutritional component for wellness programmes especially in the rural settlements where majority of the population is stricken by poverty and lack of clean water.

The consumption of Imuniti Wellness pack does not pose any danger in exceeding any of the RDA for all the product constituents analysed for. The heavy metal, pesticides and microbial levels were within acceptable WHO, BP, EMEA, EP and USP standards

No Staphylococcus. aureus, Pseudomonas aeruginosa, Salmonella species and Escherichia coli were detected in the IMUNITI sample analysed and the microbial contamination testing results were all within the WHO specifications for traditional medicinal plants (WHO, 2007).

The safety and nutritional content of studies of IMUNITI have given enough data to support the development of bigger scientific and clinical studies to now investigate its efficacy in patients infected with HIV-1.

\section{References}

1. Cornell, M., (2010). Temporal changes in programme outcomes among adult patients initiating antiretroviral therapy across South Africa, 20022007. AIDS 24(14): 2263-70

2. De Smet ,P. A., (1995). Health risks of herbal remedies. Drug Safety 13: $81-93$

3. Harrison, D., (2009). 'An Overview of Health and Health care in South Africa 1994-2010: Priorities, Progress and Prospects for New Gains'. Commissioned by the Henry J. Kaiser Family Foundation Muldersdrift, January 24 - 26 2010. www.samedical.gov.za

4. Health-e (2010). 'Provinces face drug stock outs due to overspending'. www.health-e.org.za/news/article

5. Human Sciences Research Council (2009). 'South African National HIV Prevalence, Incidence, Behaviour and Communication Survey, 2008: A Turning Tide Among Teenagers?' www.hrscpress.ac.za

6. Krakovska, O., Wahl, L.M., (2007). Optimal drug treatment regimens for HIV depend on adherence. Journal of Theoretical Biology. 246 (3): 499-509.

7. Mail \& Guardian Online (2009, March). 'Out of stock = out of life'. Mail and Guardian

8. Meyer-Rath, $\mathrm{G}$ et. al (2010) 'Total cost and potential cost savings of the national antiretroviral treatment (ART) programme in South Africa 2010 to 2017'. XVIII International AIDS conference 2010

9. National Department of Health, South Africa; South Africa National AIDS Council (2010) 'Clinical guidelines: PMTCT (Prevention of Mother-toChild Transmission)'. www.doh.gov.za/docs/factsheets/guidelines/pmtct.pdf

10. Peris Sean Jones, (2012). Mind the gap: Access to ARV medication, rights and the politics of scale in South Africa. Social Science \& Medicine 74(1); 28 - 35

11. Statistics South Africa (2008, October), 'Mortality and causes of death in South Africa, 2006: Findings from death notification' www.statssa.gov.za/Publications/statsdownload.asap?p0319.3\&SCH=4254 (Publication date 23/10/2008)

12. Statistics South Africa (2010) 'Mid-year population estimates' www.statssa.gov.za/Publications/P0302/P03022010.pdf

13. UNAIDS (2010) 'UNAIDS report on the global AIDS epidemic' www.unaids.org/downloads/20101123_GlobalReport_em.pdf

14.WHO/UNAIDS/UNICEF (2010) 'Towards Universal Access: Scaling up priority HIVIAIDS interventions in the health sector'. http://www.who.int/hiv/pub/2010progressreport/en/index.html

15. WHO (2007). Guidelines for assessing quality of herbal medicines with reference to contaminants and residues. World Health Organization, Geneva. ISBN 9789241594448 